\title{
Effect of Calcitonin Gene-Related Peptide on the Cyclic AMP Level of Isolated Mouse Diaphragm
}

\author{
Kenji TAKAMI, Kazuya HASHIMOTO*, Shuji UCHIDA*,**, \\ Masaya TOHYAMA and Hiroshi YOSHIDA* \\ Department of Neuroanatomy, Institute of Higher Nervous Activity and \\ *Department of Pharmacology 1, Osaka University Medical School. \\ 4-3-57 Nakanoshima, Kita-ku, Osaka 530. Japan
}

Accepted July 15. 1986

\begin{abstract}
The effect of calcitonin gene-related peptide (CGRP) on the cyclic nucleotide level in isolated mouse diaphragm was investigated. CGRP at concentrations of up to $1 \mathrm{kM}$ caused dose-dependent increases in cyclic AMP levels but had no effect on cyclic GMP levels. At 1 s M. CGRP increased cyclic AMP levels by about 2.7-fold. Moreover, in the presence of phosphodiesterase inhibitor (Ro 20-1724). CGRP still caused even greater dose-dependent increases in cyclic AMP levels. Even in the presence of propranolol, a beta-adrenergic antagonist, CGRP stimulated increased cyclic AMP levels. In addition, specific binding of CGRP was observed in mouse diaphragm. All these results suggest that CGRP increases intracellular cyclic AMP levels via a CGRP receptor but not the betaadrenergic receptor.
\end{abstract}

Calcitonin gene-related peptide (CGRP) is a peptide composed of 37 amino acids that is synthesized in nervous tissues by a different processing of the messenger RNA for calcitonin $(1,2)$. A wide, but non-random distribution of CGRP-like immunoreactive structures in the central and peripheral nervous system has been demonstrated by immunocytochemical studies and radioimmunoassay $(2,3)$. CGRP has been shown to cause physiological responses (4-9) and to have a binding site $(10,11)$, suggesting that it is a neurotransmitter or neuromodulator.

We observed a very wide distribution of CGRP in the central and peripheral nervous systems (3, 12-14). In these studies, we found that CGRP is localized in motor neurons and in nerve terminals of neuromuscular junctions of striated muscle where it coexists with acetylcholine (Ach) (9, 14). Furthermore, we observed that CGRP enhances the contraction of striated muscle (9). These findings suggest that it may function as a modulator of the contraction induced by Ach

** To whom correspondence should be addressed. and be important in neuromuscular transmission.

It has been shown that enhancement of muscle contraction is caused by an elevation of the intracellular cyclic AMP concentration (15-18). Therefore, in the present study, using a mouse diaphragm preparation. we examined the effect of CGRP on striated muscle and its relation to the level of cyclic AMP. In addition. we investigated the existence of specific CGRP binding sites in striated muscle.

\section{Materials and Methods}

Assay of cyclic AMP in mouse diaphragm: Male DDY mice weighing about $30 \mathrm{~g}$ were used. Under anesthetization with pentobarbital (Nembutal, $50 \mathrm{mg} / \mathrm{kg}$, i.p.), diaphragms were rapidly excised, separated from adjacent tissues, and cut in two sagitally. Until the beginning of preincubations, the preparations were stocked in Krebs-Ringer solution (bubbled with $5 \% \mathrm{CO}_{2}$ in $\mathrm{O}_{2}$ and kept at $4^{\circ} \mathrm{C}$ ). The preparations were preincubated in Krebs-Ringer solution bubbled with $5 \% \mathrm{CO}_{2}$ in $\mathrm{O}_{2}$ at $37^{\circ} \mathrm{C}$ for $5 \mathrm{~min}$, and then 
incubated with CGRP and other drugs for $3 \mathrm{~min}$. The tissues were then rapidly frozen in liquid nitrogen and stored at $-80^{\circ} \mathrm{C}$ for assay of cyclic AMP. The frozen tissues were weighed and homogenized in 10 volumes of $\mathrm{HCl}(0.1 \mathrm{~N})$ in a motor-driven microhomogenizer at $0^{\circ} \mathrm{C}$ (Tokai Irika Co.). The homogenate was centrifuged at $25,000 \mathrm{~g}$ for $15 \mathrm{~min}$ at $4^{\circ} \mathrm{C}$ and the supernatant was used for cyclic AMP assay. Cyclic AMP was measured with a kit from Yamasa Shoyu Co. using a method for radioimmunoassay involving prior succinylation of samples.

Assay of cyclic GMP in mouse diaphragm: Cyclic GMP was similarly measured with a kit from Yamasa Shoyu Co., also based on radioimmunoassay involving prior succinilation.

Assay of CGRP binding: For binding assay. the homogenate was centrifuged for $10 \mathrm{~min}$ at $1000 \mathrm{~g}$. The pellet was discarded and the supernatant was centrifuged for $10 \mathrm{~min}$ at $15,000 \mathrm{~g}$. The pellet was washed and recentrifuged twice. The final pellet was resuspended in $50 \mathrm{mM}$ Hepes/Tris buffer $\mathrm{pH} 7.4(0.5 \mathrm{~g}$ wet original tissue per $1 \mathrm{ml}$ buffer). The binding assay was carried out in a siliconized assay tube which contained $50 \mathrm{mM}$ Hepes/Tris, 1\% BSA, 10 pM 125/-
CGRP and various concentrations of cold CGRP in a total volume of $0.5 \mathrm{ml}$. The incubation was started by adding membrane protein and was carried out for $60 \mathrm{~min}$ at $6{ }^{\circ} \mathrm{C}$. After incubation, the samples were centrifuged for 5 min using an Eppendorf 54BS table centrifuge and the supernatant was sucked off. The pellet was washed with $0.5 \mathrm{ml}$ ice cold buffer up to 3 times. A $5 \mathrm{~mm}$ section of the assay tube containing the pellet was cut off, put into a $3 \mathrm{ml}$ plastic tube and counted in a gamma counter.

Drugs: The following drugs were used: rat calcitonin gene-related peptide (Peninsula Laboratories); theophylline, papaverine hydrochloride, dl-propranolol hydrochloride (Wako Pure Chemical Industries): Ro 20-1724 (Roche Research Laboratory) and 125/. calcitonin gene-related peptide (Amersham).

Statistics: Statistical significance was calculated by Student's t-test.

\section{Results}

Effects of CGRP on the tissue levels of cyclic AMP and cyclic GMP: Incubation of the hemi-diaphragm with $0.1 \mu \mathrm{M}$ CGRP caused 1.8-fold increases in cyclic AMP levels within $1 \mathrm{~min}$. The peak level was maintained for at least $10 \mathrm{~min}$ (Fig. 1). Con-

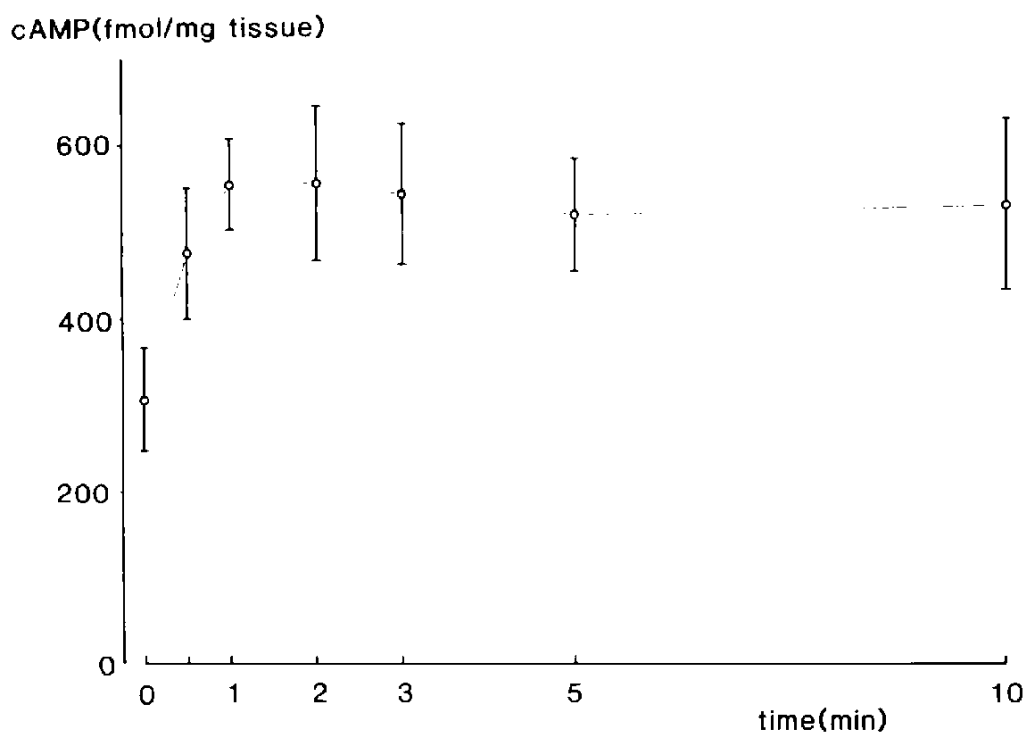

Fig. 1. Time course of changes in cyclic AMP levels in mouse diaphragm induced by CGRP $(0.1, \mu \mathrm{M})$. Points and bars represent means \pm S.D., respectively $(n=5)$. 
centrations of from $10 \mathrm{nM}$ to $1 / \mu \mathrm{M}$ CGRP caused dose-dependent increases in cyclic AMP levels (Fig. 2); even at $1, \mu \mathrm{M}$ CGRP cyclic AMP levels ( $266 \%$ of the control) did not reach a plateau (Fig. 2A).

Cyclic GMP levels $(44.6 \pm 4.7 \mathrm{fmol} / \mathrm{mg}$ tissue, $n=4)$, however, were not significantly affected by $1 \mu \mathrm{M}$ CGRP $(48.2 \pm 8.3 \mathrm{fmol} / \mathrm{mg}$ tissue, $n=4$ ), even by the end of 3 min, at which time cyclic AMP levels had already risen dramatically (Fig. 1).

Effect of phosphodiesterase inhibitors on

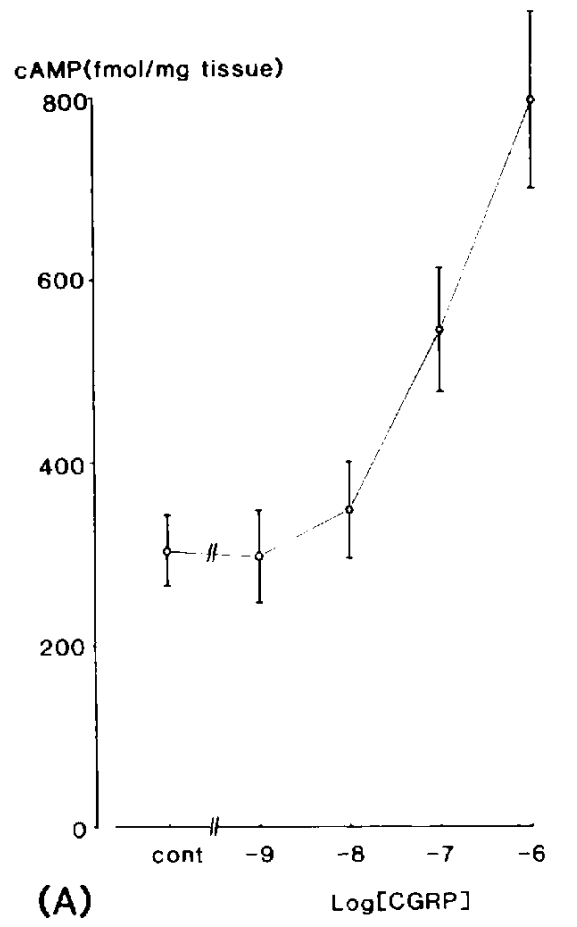

CGRP-induced increases in cyclic AMP levels: The effects of the phosphodiesterase inhibitors theophylline (1 $\mathrm{mM})$, papaverine (30 $\mu \mathrm{M})$ and Ro 20-1724 (0.3 mM) on level of cyclic AMP were investigated. These compounds all raised the tissue levels of cyclic AMP, as shown in Table 1. Ro 201724, which had the greatest effect, increased the cyclic AMP level 6.6 -fold during a $3 \mathrm{~min}$ incubation, while other compounds increased it about 2-fold. In the presence of these compounds, CGRP $(0.1 \mu \mathrm{M})$ increased the

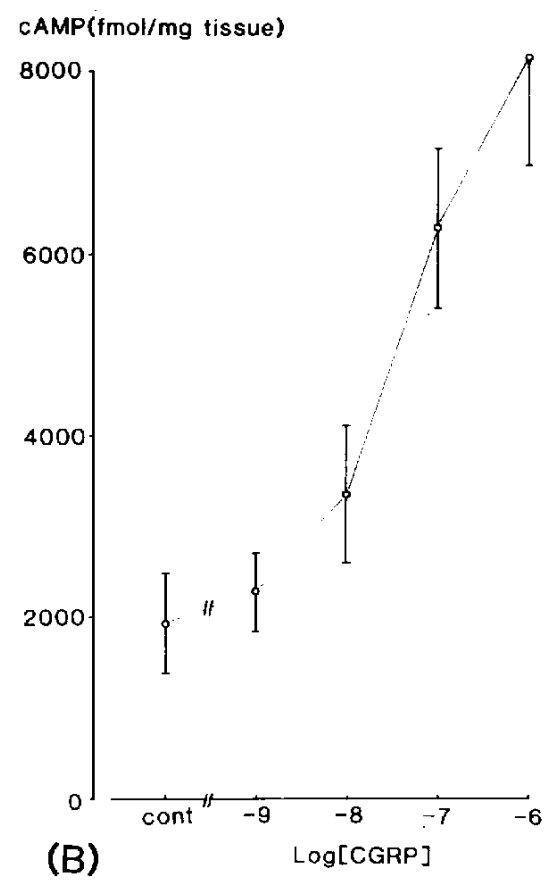

Fig. 2. Dose response curve of CGRP $(0.1 \mu \mathrm{M})$ effect on cycilic AMP levels in mouse diaphragm (A) and in the presence of a phosphodiesterase inhibitor (Ro 20-1724:0.3 mM) (B). Points and bars represent means \pm S.D. $(n=5)$.

Table 1. Effect of CGRP $(0.1 \mu \mathrm{M})$ on cyclic AMP levels in mouse diaphragm in the absence and presence of phosphodiesterase inhibitors

\begin{tabular}{lcccc}
\hline Treatment & \multicolumn{2}{c}{ Cyclic AMP (fmol/mg tissue) } & $\mathrm{n}$ \\
& CGRP $(-)$ & CGRP(+) & $(+) /(-)$ & \\
Control & $312 \pm 42^{*}$ & $571 \pm 89$ & 1.83 & 5 \\
Theophylline $(1.0 \mathrm{mM})$ & $608 \pm 98^{*}$ & $1409 \pm 251^{*}$ & 2.31 & 5 \\
Papaverine $(30 \mu \mathrm{M})$ & $769 \pm 135^{*}$ & $2829 \pm 452^{*}$ & 3.67 & 5 \\
Ro 20-1724 $(0.3 \mathrm{mM})$ & $2051 \pm 651^{*}$ & $5461 \pm 1455^{*}$ & 2.66 & 5 \\
\hline
\end{tabular}

Values are meanstS.D. * $(P<0.01)$ significantly different from control. 
cyclic AMP level 2.3-3.7 fold further in $3 \mathrm{~min}$ (Table 1: CGRP $(+) / \operatorname{CGRP}(-)$ ). The activation ratios $((+) /(-))$ in the presence of phosphodiesterase inhibitors were higher than in their absence. Figure 3 shows the dose-dependent increase of cyclic AMP produced by CGRP in the presence of Ro 201724.

Effect of propranolol on CGRP-induced

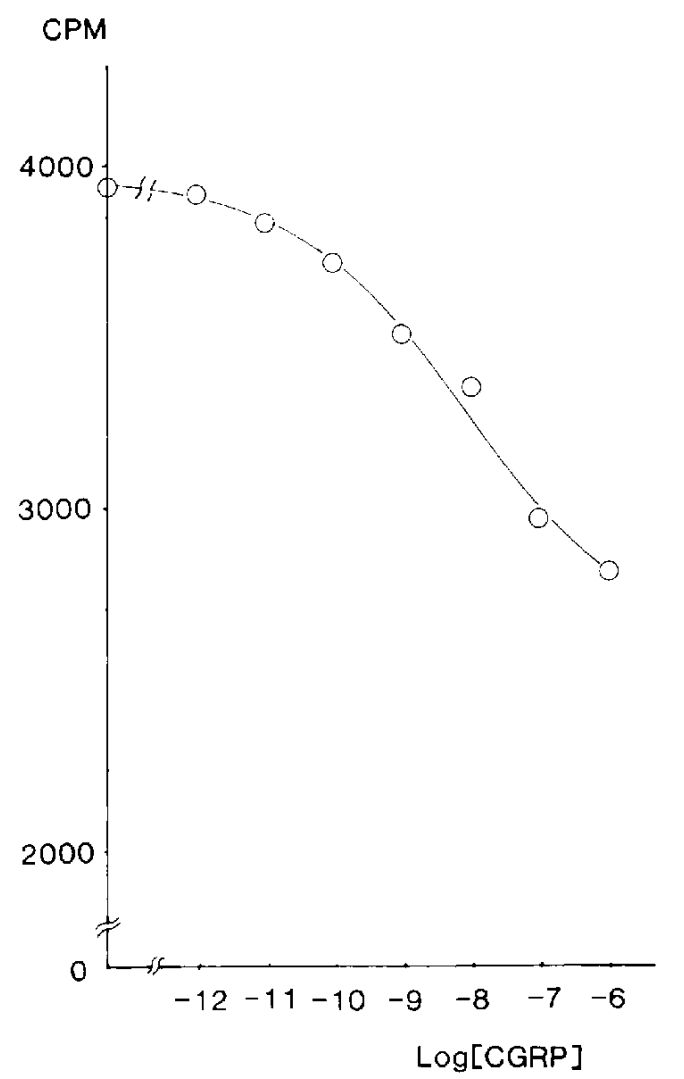

Fig. 3. Displacement of 125/-CGRP binding by CGRP. Points represent means of the experiment performed in duplicate. increases in cyclic AMP levels: Betaadrenergic agonists are known to increase the cyclic AMP level and enhance contraction of striated muscle. Therefore, we examined whether CGRP had an effect via the beta-adrenergic system. In the presence of propranolol $(1, \mu \mathrm{M})$, CGRP increased the cyclic AMP level 2.0-fold (Table 2). Moreover, CGRP $(0.1 \mu \mathrm{M})$ enhanced muscle contraction in response to under direct stimulation of the diaphragm even in the presence of propranolol (1 $\mu \mathrm{M}$ ) (data not shown). These findings indicate that the effects of CGRP on the cyclic AMP level and muscle contraction are not mediated by the betaadrenergic system.

Assay of CGRP binding: Specific binding of CGRP was observed. Figure 3 shows that bound 125/-CGRP was displaced with cold CGRP, characterized by $1 \mathrm{C} 50$-value of $50 \mathrm{nM}$.

\section{Discussion}

Several biological effects of CGRP have been reported (4-9). Previously we reported that CGRP coexists with Ach in motor nuclei and neuromuscular junctions, and enhances the contraction of the striated muscle stimulated either directly or by nerves $(9,14)$. But little is known about the mechanism of this effect.

In the present study, we examined whether the effect of CGRP on muscle contraction was related to cyclic AMP accumulation. Results showed that CGRP increased cyclic AMP levels in mouse diaphragm; at concentrations of up to $1 \mu \mathrm{M}$. it increased tissue levels of cyclic AMP up to 2.7-fold in a dosedependent manner. Previously, we reported that the enhancement of witch contractions of diaphragmatic muscle induced by CGRP during nerve or direct stimulation first oc-

Table 2. Effect of CGRP on cyclic AMP levels in mouse diaphragm in the presence and absence of propranolol

\begin{tabular}{lcc}
\hline Treatment & Cyclic AMP (fmol/mg tissue) & $n$ \\
Control & $-. .02 \pm 56$ & 5 \\
dl-Propranolol $(1.0 \mu \mathrm{M})$ & $305 \pm 70$ & 5 \\
CGRP $(0.1 \mu \mathrm{M})$ & $622 \pm 63^{*}$ & 5 \\
CGRP $(0.1 \mu \mathrm{M})$ and dl-propranolol $(1.0 \mu \mathrm{M})$ & $630 \pm 118^{*}$ & 5 \\
\hline
\end{tabular}

Values are means \pm S.D. *: $(P<0.01)$ significantly different from control. 
curred within one minute $(9,14)$. As shown in Fig. 1, its effect of CGRP on cyclic AMP levels was sufficient to produce prompt enhancement of the twitch contraction.

Theophylline, papaverine and Ro 20-1724. which are phosphodiesterase inhibitors. caused significant increases in tissue levels of cyclic AMP (Table 1). Moreover, CGRP increase cyclic AMP levels more in the presence of these phosphodiesterase inhibitors than in their absence (Fig. 2B and Table 1). These data support the existence of CGRP-stimulated adenylate cyclase activity in the membrane fraction of rat diaphragm (H. Kobayashi et al., unpublished data).

In striated muscle, beta-adrenergic agonists are reported to increase the level of cyclic AMP, and beta-adrenergic agonists. dibutyryl cyclic AMP and phosphodiesterase inhibitors all enhance muscle contraction under either nerve or direct stimulation (1518). Under such conditions, adrenergic agonists might enhance twitch contraction of muscle mediated by an intracellular cyclic AMP. Increases in cyclic AMP levels may well mediate diverse effects on the metabolism of striated muscle cells, such as the defatiguing effect of adrenaline. Enhanced twitch contraction is probably one result of these diverse effects. Our results with CGRP and the previously reported effects of betaagonists and dibutyryl-cyclic AMP indicate that enhancement of contraction may be relate to increased intracellular levels of cyclic AMP.

The effect of CGRP was not mediated by beta-adrenergic receptors, because it increased cyclic AMP levels and enhanced muscle contraction even in the presence of propranolol (data not shown). We reported previously that the effect of CGRP was also not mediated via the nicotinic receptor (9). In this study, we showed that specific CGRP binding sites exist on the muscle membrane. Accordingly. CGRP may activate adenylate cyclase in the muscle by binding to a CGRP receptor on the muscle plasma membrane.

Acknowledgements: The authors thank Mieko Nakamura for secretarial assistance and Roche Research Laboratory for the generous gift of Ro $20-1724$.

\section{References}

1 Amara, S.G., Jonas, V., Rosenfeld, M.G., Ong, E.S. and Evans, R.M.: Alternative RNA processing in calcitonin gene expression generates mRNAs encoding different polypeptide products. Nature 298, 240-244 (1982)

2 Rosenfeld, M.G., Mermord, J.-J., Amara, S.G., Swanson, L.W., Sawchenko, P.E., Rivier, J., Vale, W.W. and Evans, R.M.: Production of a novel neuropeptide encoded by the calcitonin gene via tissue specific RNA processing. Nature 304, 129-135 (1983)

3 Kawai, Y., Takami, K., Shiosaka, S., Emson, P.C., Hillyard, V.J., Girgis, S., Macintyre, I. and Tohyama, M.: Topographic localization of calcitonin gene-related peptide in the rat brain: an immunohistochemical analysis. Neuroscience $15,747-763$ (1985)

4 Fisher, L.A., Kikkawa, D.O., Rivier, J.E., Amara, S.G., Evans, R.M., Rosenfeld, M.G., Vale, W.W. and Brown, M.R.: Stimulation of noradrenergic sympathetic outfiow by calcitonin gene-related peptide. Nature 305, 534-536 (1983)

5 Krahn, D.D., Gosnell, B.A., Levine, A.S. and Morley, J.E.: Effect of calcitonin gene-related peptide on food intake. Peptide 5, 861-864 (1984)

6 Mason, R.T., Peterfreund, R.A., Sawchenko, P.E., Corrigen, A.Z., Rivier, J.E. and Vale, W.W.: Release of the predicted calcitonin gene-related peptide from cultured rat trigeminal ganglion cells. Nature 308, 653-655 (1984)

7 Wiesenfeld-Hallin, Z., Hokfelt, T., Lundberg, J.M., Forssmann, W.G., Reinecke, M., Tschopp, F.A. and Fischer, J.A.: Immunoreactive calcitonin gene-related peptide and substance $P$ coexist in sensory neurons of the spinal cord and interact in spinal behavioral responses of the rat. Neurosci. Lett. 52, 199-204 (1984)

8 Brain, S.D., Williams, T.J., Tippins, J.R., Morris, H.R. and Maclntyre, I.: Calcitonin gene-related peptide is a potent vasodilator. Nature 313,54 56 (1985)

9 Takami, K., Kawai, Y., Uchida, S., Tohyama, M., Shiotani, Y., Yoshida, H., Emson, P.C., Girgis, S., Hillyard, C.J. and Maclntyre, I.: Effect of calcitonin gene-related peptide on contraction of striated muscle in the mouse. Neurosci. Lett. 60 , 227-230 (1985)

10 Seifert, H., Chesnut, J., Rivier, J. and Vale, W.: Calcitonin gene related peptide: High affini:y binding sites in rat brain. Soc. Neurosci. Abstr. 10, 379 (1984)

11 Tschopp, F.A., Henke, H., Petermann, J.B., Tobler, P.H., Janzer, R., Hokfelt, T., Lundberg, 
J.M., Cuello, C. and Fischer, J.A.: Calcitonin gene-related peptide and its binding sites in the human central nervous system and pituitary. Proc. Natl. Acad. Sci. U.S.A. 82, 248-252 (1985)

12 Lee, Y., Kawai, Y., Shiosaka, S., Takami, K., Kiyama, H., Hillyard, C.J., Girgis, S., Maclntyre, I., Emson, P.C. and Tohyama, M.: Coexistence of calcitonin gene-related peptide and substance P-like peptide in single cells of trigeminal ganglion of the rat: Immunohistochemical analysis. Brain Res. 330, 194-196 (1985)

13 Lee, Y., Takami, K., Kawai, K., Shiosaka, S., Girgis, S., Hillyard, G.J., Maclntyre, I., Emson, P.C. and Tohyama, M.: Distribution of calcitonin gene-related peptide in the peripheral nervous system with special reference to their coexistence with substance $P$ in the rat. Neuroscience 15 , 1227-1237 (1985)

14 Takami, K., Kawai, Y., Shiosaka, S., Lee, Y., Girgis, S., Hillyard, C.J., Maclntyre, I., Emson, P.C. and Tohyama, M.: Immunohistochemical evidence for the coexistence of calcitonin generelated peptide- and choline acetyltransferaselike immunareactivity in neurons of the rat hypoglossal, facial and ambiguns nuclei. Brain Res. 328, 386-389 (1985)

15 Sullivan, A. and Zaimis, E.: The effect of isoprenaline on cyclic AMP concentrations in skeletal muscle. J. Physiol. (Lond.) 231, 102P103P (1973)

16 Kentera, D. and Varagic, V.M.: The effect of cyclic N-2-O-dibutyryl-adenosine $3^{\prime}, 5^{\circ}$-monophosphate, adrenaline and aminophylline on the isometric contractility of the isolated hemidiaphragm of the rat. Br. J. Pharmacol. 54, 375-381 (1975)

17 Varagic, V.M. and Kentera, D.: Interaction of calcium, dibutyryl cyclic AMP, isoprenaline and aminophylline on the isometric contraction of the isolated hemidiaphragm of the rat. Naunyn Schmiedebergs Arch. Pharmacol. 303, 47-53 (1978)

18 Rodger, I.W. and Bowman, W.C.: Adrenoceptors and skeletal muscle. In Adrenoceptors and Catecholamine Action. Part B. Edited by Kunos. G., p. 123-155, John Wiley \& Sons, Inc.. New York (1982) 